\title{
唾液腺腫瘍病理組織像と MRI
}

\author{
楠＼cjkstart威志・村田 清高 \\ Histopathological Findings and MRI in Salivary Gland Tumors
}

Takeshi Kusunoki and Kiyotaka Murata

(Kinki University)

\begin{abstract}
We studied the correlation between postoperative histological findings and signal intensities of preoperative magnetic resonance (MR) imaging in parotid tumors and submandibular gland tumors. Most cancer cases showed low signal intensities on T1 weighted MRI and an enhanced effect regardless of differentiated grades. However, our results showed that low signal intensities on T2 weighted MRI indicated low and moderately differentiated cancers, and reversely high signal intensities on T2 indicated highly differentiated cancers. These findings may be useful to plan surgical methods and to predict the prognosis.
\end{abstract}

Key words : histopathological findings, MRI, salivary gland tumors

はじめに

唾液腺腫瘍の診断に対し MRI が有用であることはす でに報告されている11。睡液腺は頸部に位置する浅在性 の藏器であるため，日常診療に乱ける診断には問診拉よ び，訓練された視触診が最も重要である23)．実際，当 科の調查でも耳下腺腫瘍の良性腫瘍の良性，悪性の鑑別 の久であれば視触診, 特に硬さ, 疼痛の有無, 腫瘍の可 動性の有無の組み合わせで十分高い正診率が得られた4). しかし，腫瘍が下顎骨内側に入り込んでいたり，副咽頭 間隙に進展した場合などのごとく触診が困難な時は MRI が有用である。また，MRI は術前，腫瘍周团の臓器と の関連が把握でき，術式決定に貴重な情報を提供してく れる場合がある，さらに良性，悪性の鑑別にも有用であ る．以上の有用性の他に本論文では腫瘍の分化度まで鑑 別できるか否かについて検討した。

\section{対象と方法}

\section{1. 対 象}

1992年 4 月 1 日から1998年10月までの間に近畿大学医 学部附属病院耳鼻咽喉科飞乱いて耳下腺敊よび钼下腺癌
手術症例18例のらち, 術前何らかの目的で MRI 検査を 施行した16例を対象とした。また，1997年 8 月までの間 に, 当科に扮いて耳下腺拉よび顎下腺良性腫瘍手術症例 18例のらち術前 MRI 検查を施行した13例を対象とした。 その内訳は表 1 亿示すごとく，粘表皮腫 4 例，腺房細胞 腫 1 例, 腺様囊胞癌 6 例, 腺癌 1 例, 扁平上皮癌 1 例, 腺扁平上皮癌 1 例, 多形腺腫内癌 2 例, 良性多形腺腫 7 例，ワルチン腫瘍 6 例であった。

\section{表 1 病理組織像}

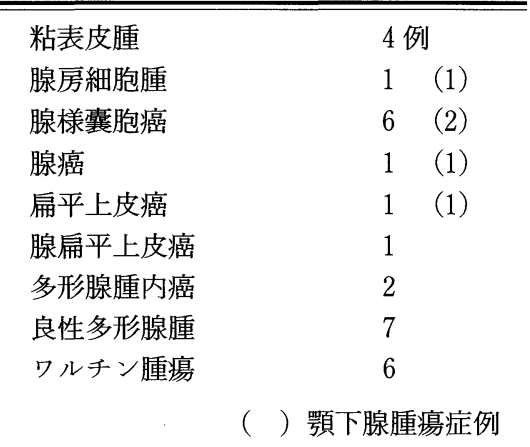


2. 方 法

MRI 撮影方法はスピンェコー法で $\mathrm{T} 1$ 強調像, T2 強 調像を用い, 軸位断層後, $\mathrm{T} 1$ 強調像で冠状断像を追加 した. 症例によっては, ガドリニウム造影を施行した. 各 症例飞括いて腫瘍内の $\mathrm{T} 1$ 強調像扰よび $\mathrm{T} 2$ 強調像の信 号強度は, 健側耳下腺および顎下腺を基準にして高, 等, 低信号の 3 段階に分類した. 後述する表 2 亿, 高信号を $\mathrm{H}$, 等信号を $\mathrm{I}$ ，低信号をLと表示した。なお，検討部 位が腫瘍充実部であり, 出血, 壊死, 霊胞变性などの 2 次的変化でないことは病理組織学的検索にて確認した. 表 2 亿分化度を記載した. 癌の分化度の判定は, 細胞異 型, 構造異型の程度などを参考にした。扁平上皮癌の分 化度は Lucas ${ }^{5)}$ の分類に準じて以下のようにした。. 高分 化型は角化傾向拉よび癌真珠を認め, 核異型性に之しく, 胞巣が明瞭であるもの, 中分化型は癌真珠は認めないが 角化傾向を認め胞巣を形成するもの, 低分化型は癌真珠 がなく, 角化傾向がなく, 胞巣形成がないものとした。 粘表皮腫の分化度は以下のようにした ${ }^{6)}$. 高分化型は粘 液産生細胞が多く, 囊胞様の所があり, 粘液産生細胞, 扁平上皮類似細胞, 中間型細胞の 3 構成成分が分かれて 存在するもの, 低分化型は扁平上皮類似細胞が多く, 粘 液産生細胞, 扁平上皮類似細胞, 中間型細胞の 3 構成成
分が混在するものとした．腺様囊胞癌については, 構造 形態を篩管型, 管状型, 索状型, 充実型に分類した. 上 記の型が同一症例に複数混在している際は, 優位に占め ているものを上位 2 型を右より記載した。例えば篩管型 が管状型より優位な時は篩管型＞管状型とした．Perzin ら7)の分類に準じて充実型を低分化型とし，それ以外を 高分化型とした.

\section{結 果}

表 2 より, 悪性喠液腺腫瘍のらち粘表皮腫, 腺扁平上 皮癌の低抒よび中分化型は $\mathrm{T} 1, \mathrm{~T} 2$ 強調像共飞低信号を 示した。病理組織像に括いては異型性が高かった。低分 化型粘表皮腫の病理組織像に括いては粘液産生細胞より 扁平上皮癌の部分が優位のため粘液産生も乏しかった。 逆に, 粘表皮腫, 腺癌, 扁平上皮癌の高分化型では $\mathrm{T} 1$ 強調像では低信号を示したが $\mathrm{T} 2$ 強調像では高信号を 示した。 それらの病理組織像に招いては異型性が低かっ た. 高分化型粘表皮腫に括いては粘液産生細胞が多く, 小霊胞内腔飞粘液貯留を認めた。腺様囊胞癌では 6 例中 4 例が前述した高分化癌と同様, T1 強調像で低信号, $\mathrm{T} 2$ 強調像では高信号を示した。病理組織像では篩管型 扣よび管状型が大部分を占め内腔に粘液貯留を認めた

表 2 悪性唾液腺腫瘍の MRI

\begin{tabular}{|c|c|c|c|c|c|}
\hline 症 例 & & $\mathrm{T} 1$ 強調像 & $\mathrm{T} 2$ 強調像 & 造影検査 & 分化度 \\
\hline \multirow[t]{4}{*}{ 粘表皮腫 } & 1 & $\mathrm{~L}$ & $\mathrm{H}$ & 施行せず & 高 \\
\hline & 2 & $\mathrm{~L}$ & $\mathrm{H}$ & + & 高 \\
\hline & 3 & $\mathrm{~L}$ & $\mathrm{~L}$ & 施行せず & 低 \\
\hline & 4 & $\mathrm{~L}$ & $\mathrm{~L}$ & + & 低 \\
\hline 腺房細胞腫 & 5 & I & $\mathrm{H}$ & 施行せず & \\
\hline \multirow[t]{6}{*}{ 腺様囊胞癌 } & 6 & $\mathrm{~L}$ & $\mathrm{H}$ & + & 管 状 \\
\hline & 7 & $\mathrm{~L}$ & $\mathrm{H}$ & + & 穊 管 \\
\hline & 8 & $\mathrm{~L}$ & $\mathrm{H}$ & 施行せず & 飾管 $>$ 管状 \\
\hline & 9 & $\mathrm{~L}$ & $\mathrm{H}$ & + & 篩管＞管状 \\
\hline & 10 & $\mathrm{~L}$ & $\mathrm{~L}$ & + & 充実>索状 \\
\hline & 11 & $\mathrm{~L}$ & $\mathrm{~L}$ & + & 充 実 \\
\hline 腺＼cjkstart癌 & 12 & $\mathrm{~L}$ & $\mathrm{H}$ & + & 高 \\
\hline 扁平上皮癌 & 13 & $\mathrm{~L}$ & $\mathrm{H}$ & + & 高 \\
\hline 腺扁平上皮癌 & 14 & $\mathrm{~L}$ & $\mathrm{~L}$ & + & 中 \\
\hline \multirow[t]{3}{*}{ 多形腺腫内癌 } & 15 & $\mathrm{~L}$ & $\mathrm{H}$ & + & \\
\hline & 16 & $\mathrm{~L}$ & $\mathrm{H}$ & 施行せず & \\
\hline & \multicolumn{2}{|c|}{$\begin{array}{l}\mathrm{H}: \text { 高信号 } \\
\mathrm{I}: \text { 等信号 } \\
\mathrm{L} \text { : 低信号 } \\
+\mathrm{I} \text { 造影効果あり }\end{array}$} & $\begin{array}{l}\text { 高 : 高分化型 } \\
\text { 中 : 中分化型 } \\
\text { 低 : 低分化型 }\end{array}$ & & \\
\hline
\end{tabular}




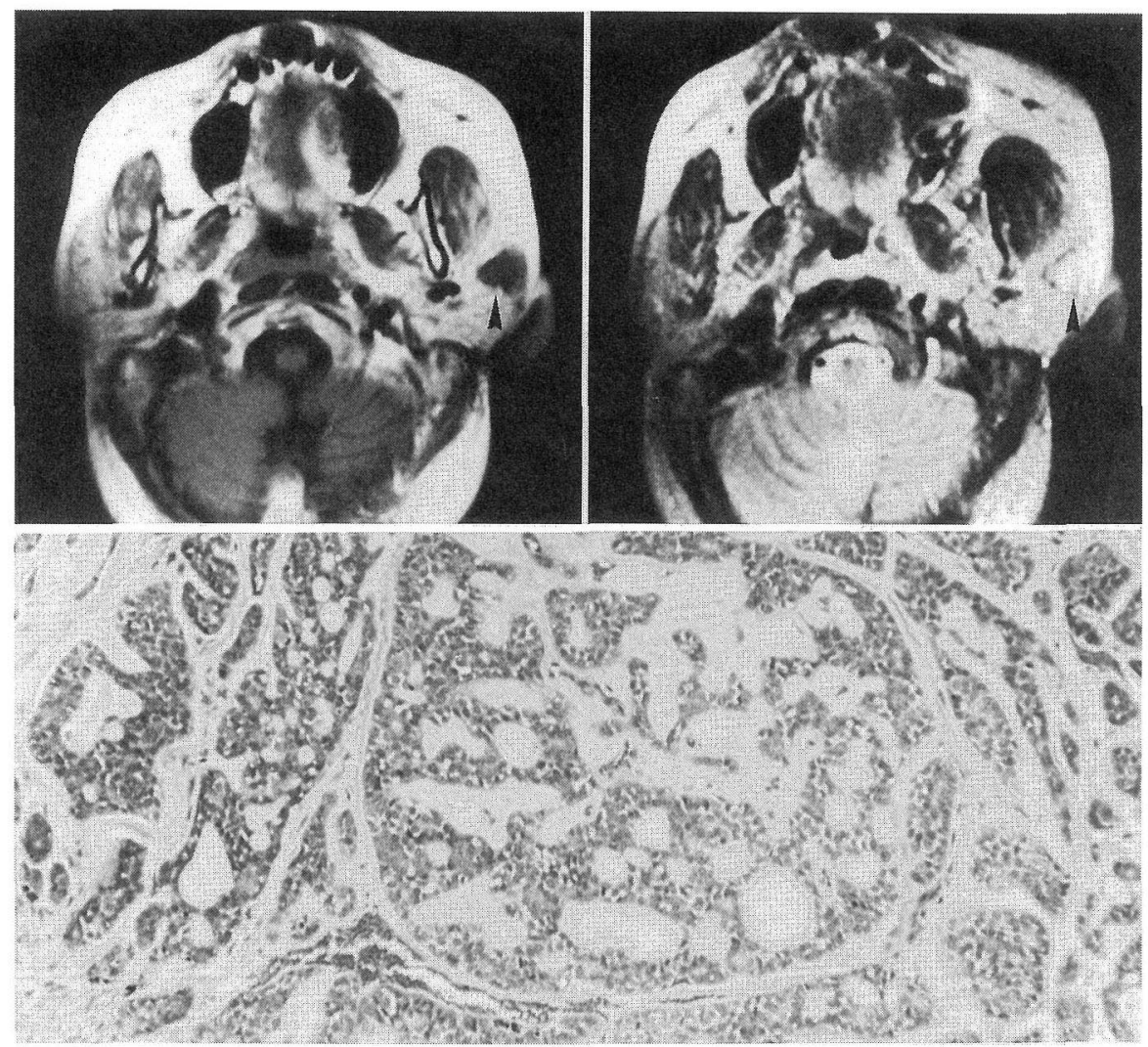

図 1 篩管型腺様囊胞癌(症例 7 )

MRI 像(上段)：T1 強調像(左)で低信号，T2 強調像(右)で高信号を示した. 病理組織像 $(\mathrm{HE}$ 染色 $\times 80$, 下段)：腫瘍細胞が篩管状配列を示し，腺腔内に粘液 を豊富に認める。

（図 1 ）。炎の他 2 例は前述した低分化型癌同様，T1，T 2 強調像共に低信号を示した。病理組織像では腫瘍細胞 が充実性に増殖し粘液産生像は少なかった（図 2 )。多形 腺腫内癌種の 2 例は，前述乙た高分化癌と同様， T1 強 調像で低信号，T2 強調像では 高信号を示した。その 2 例の病理組織像は，良性多形腺腫と同様に上皮細胞成分， 軟骨様, 粘液腫様構造から成り分化は保たれ， 壬とえど 異型性を示さなかった。しかし，一部被膜内执よび毛細 血管に侵襲を認めた．腺房細胞腫は印環細胞型を示し， 異型性は軽度であった。 MRI 像では T1 強調像で等信 号， T2 強調像では高信号を示した。造影検査施行症例 をみると，組織像物よび分化度に関係なく増強されてい た。

表 3 より，良性腫瘍では多形腺腫 7 例全例が高分化癌 と同様，T1強調像で低信号，T2強調像では高信号を 示し, 造影検査施行 6 症例全例に拈いて増強されていた。
ワルチン腫瘍は 6 例全例, $\mathrm{T} 1$ 括よび $\mathrm{T} 2$ 強調像共に低 信号を示した. 全例病理組織像は大部分がリンパ間質で あった。 また造影検査施行 4 症例全例に持いて造影効果 は認められなかった。

\section{考察}

覀性唾液腺腫瘍では，粘表皮腫，腺扁平上皮癌で低特 よび中分化型, 腺様桽胞癌に执いて充実型で異型性の高 いものは，T2 強調像に和いて低信号を示す傾向にあっ た。逆に粘表皮腫, 腺癌, 扁平上皮癌で高分化型, 腺様 裹胞癌に执いて篩管型执よび管状型を示し，分化した多 形腺腫内癌のよらに異型性の低いものは, T2 強調像に 扣いて高信号を示す傾向にあった。一般的に腫瘍は MRI は緩和時間が延長し，T1 強調像では低〜等信号を T2 強調像では高信号を呈するとされている8). その理 由は腫瘍組織では含水量が高く自由水の割合が多いため 

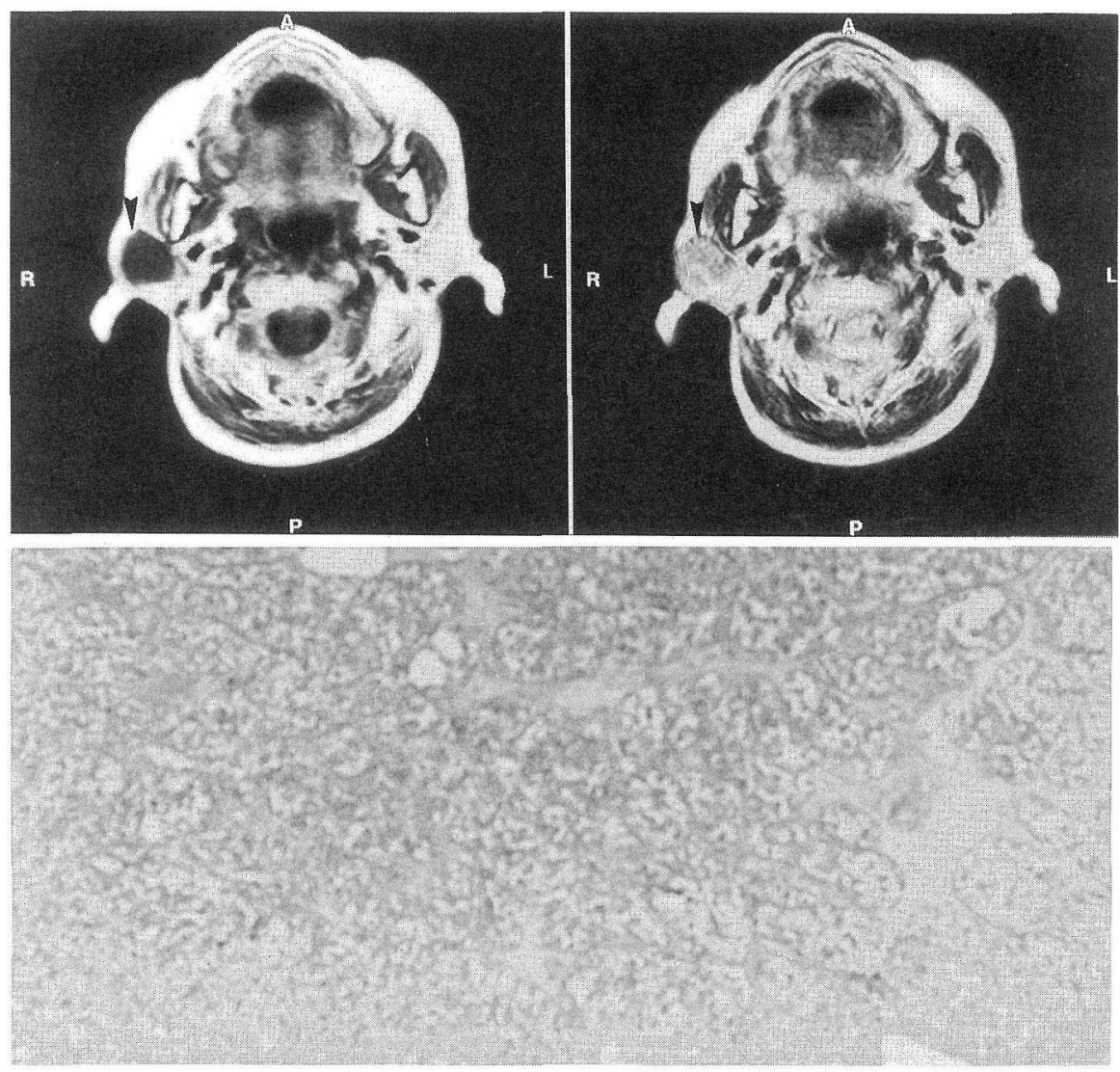

図 2 充実型腺様囊胞癌(症例11)

MRI 像(上段)：T1 強調像(左)，T2 強調像(右)共に低信号を示した.

病理組織像 $(\mathrm{HE}$ 染色 $\times 80$, 下段 $)$ : 病変部全体に腫瘍細胞が充実性に増殖し粘液 産生が乏しい。

表 3 良性唾液腺腫瘍の MRI

\begin{tabular}{ccccc}
\hline \hline 症 例 & & T1 強調像 & T2 強調像 & 造影検査 \\
\hline 多形腺腫 & 1 & $\mathrm{~L}$ & $\mathrm{H}$ & + \\
& 2 & $\mathrm{~L}$ & $\mathrm{H}$ & + \\
& 3 & $\mathrm{~L}$ & $\mathrm{H}$ & + \\
& 4 & $\mathrm{~L}$ & $\mathrm{H}$ & + \\
& 5 & $\mathrm{~L}$ & $\mathrm{H}$ & 施行せず \\
& 6 & $\mathrm{~L}$ & $\mathrm{H}$ & + \\
ワルチン腫瘍 & 8 & $\mathrm{~L}$ & $\mathrm{H}$ & + \\
& 9 & $\mathrm{~L}$ & $\mathrm{~L}$ & 施行せず \\
& 10 & $\mathrm{~L}$ & $\mathrm{~L}$ & 施行せず \\
& 11 & $\mathrm{~L}$ & $\mathrm{~L}$ & - \\
& 12 & $\mathrm{~L}$ & $\mathrm{~L}$ & - \\
& 13 & $\mathrm{~L}$ & $\mathrm{~L}$ & - \\
& $\mathrm{H}:$ 高信号 & L : 造影効果むり & \\
& $\mathrm{L}:$ 低信号 & - : 造影効果なし &
\end{tabular}


とされている。しかし Som ら99 は, 耳下腺腫瘍におい て低分化で異型性が強く, N/C が高いものは組織体積 あたりの水分量の減少のため $\mathrm{T} 2$ 強調像は低信号を示す としている.この報告と自験例和いて低分化癌が $\mathrm{T} 2$ 強調像にて低信号を示す傾向にあることもこともらなず ける，唾液腺腫瘍は良性，悪性を問わず多少なりともム チンなぞ粘液を産生する。そのためムチンは高蛋白のた め常磁性効果に $\mathrm{T} 1$ 短縮をさたし, 内容液がムチンの囊 胞疾患では $\mathrm{T} 1$ 強調像で高信号を示す8) とされている. しかし, 腺房細胞腫 1 例は $\mathrm{T} 1$ 強調像で等信号であった がそれ以外良性, 悪性共に $\mathrm{T} 1$ 強調像で低信号を示し, 高信号症例はなかった。これは検討した部位が囊胞疾患 ではなく腫瘍充害部であったことによると考兄る．高分 化癌, 良性腫瘍であっても腫瘍充実部領域のムチン産生 に関しては MRI に影響はなさそらである.T2強調像 そ扮いては低分化癌は, 高分化癌より粘液産生が乏しい ことも少なくとも高信号になりにくい因子となる．T1 強調像では分化度, 異型性の程度に関係なくほとんどが 低信号を示すことを考学ると，腫瘍の分化度を予測する のには T2 強調像を見る方が都合がよいと思われる。

良性腫瘍をみると，多形腺腫全症例に扮いて分化度は 保たれ異型性が乏しいため T2 強調像は高信号であった。 しかし，ワルチン腫瘍では前述した低分化癌と同様 T2 強調像にて低信号を示した. 今回検討から除外したが， 囊胞変性を伴らワルチン腫瘍では, T2 強調像にて高信 号を示すとされている10)。今回, 全例病理組織像では大 部分がリンパ間質であり，そのリンパ間質は低信号を示 すとされている10). 造影検査では施行症例全例において 造影効果は認めなかった。ワルチン腫瘍と低分化癌との 鑑別に造影検查が有用なのかもしれない。

粘表皮腫, 腺癌, 扁平上皮癌, 腺扁平上皮癌に拈いて 高分化型より低分化型，また腺様囊胞癌では篩管型执よ び管状型より充実型のほうが転移, 再発しやすく予後が 悪い11) 13). ゆ兄に術前に今回の上うに MRI T2 強調像 をみることによって唾液腺腫瘍の分化度, 異型性を予測 することは，治療方針，術式決定に有用である. しかし， あくまで術前に, 検討部位が腫瘍充実部であり, 出血, 壊死, 豊胞変性など 2 次的変化でないことが前提となる. 特に血液, ムチンを含んだ霬胞疾患は $\mathrm{T} 2$ 強調像で高信 号となる ${ }^{8)}$ そそのためェコーの性状, 穿刺吸引内容液の 色，量などが参考になる。亦た造影検查も囊胞变性では 増強されないことも, 増強される腫瘍充実病変との鑑別
に有用と考える.

$$
\text { まとめ }
$$

耳下腺特よび顎下腺腫瘍の病理組織像と術前 MRI 信 号強度とを比較検討した。注とんどの癌症例では分化 度と関係なく $\mathrm{T} 1$ 強調像で低信号を示し，造影効果を認 めた。しかし，低拉よび中分化癌は T2 強調像にて低信 号を示す傾向にあり, 逆に高分化癌は T2 強調像にて高 信号を示す傾向にあった。

\section{参考文献}

1) Casselmen JW and Mancuso AA : Major salivary gland masses ; comparison of MR imaging and CT. Radiology $165: 183 \sim 189,1987$.

2 ) 鶴田至宏, 佐藤武男, 宮原 裕, 他: 唾液腺腫瘍92例の臨 床統計. 日䕗 $89: 724 \sim 730,1986$.

3 ）金子まどか, 柊 光一, 古川政樹, 他 : 耳下腺腫瘍の統計 的観察. 耳鼻 $33: 261 \sim 268,1987$.

4) 楠 威志, 村田清高, 細井裕司: 唾液腺腫煌の理学的所見 とよる良性・悪性の鑑別.耳鼻 $42 ： 129 \sim 135,1996$.

$5)$ Lucas RB : Epidermoid tumors. Pathology of Tumors of the Oral Tissue. (2nd ed ed by Lucas RB). pp 121 146, Churchill Livingstone, London, 1972.

6) 村上 泰：口腔癌の腫瘍組織からみた悪性度と予後. JOHNS $1.6: 170 \sim 179,1990$.

7) Perzin KH, Callane P and Clarmout AC : Adenoid cystic carcinomas arising in salivary glands. Cancer $42: 265 \sim$ 284, 1978.

8 ）三浦寿美子, 多田信平：MRI の基礎知識. JOHNS 10 : 1311 1327, 1989.

9) Som PM and Biller HF : High-grade malignancies of the parotid gland ; identification with MR imaging. Radiology $173: 823 \sim 826,1989$.

10）岩井大, 池田耕一, 田中敬正, 他：ワルチン腫瘍の MRI. 耳搌頭頸 $66: 180 \sim 181,1994$.

11）長尾孝一：耳下腺腫瘍の病理. 耳下腺腫瘍（奥田 稔, 金 子敏郎編). $8 \sim 47$ 頁, 文光堂, 東京, 1987 .

12) Healey WV, Perzin KH and Smith L : Mucoepidermoid carcinoma of salivary gland origin ; classification, clinical pathologic correlation, and results of treatment. Cancer $26: 368 \sim 388,1970$.

13) Eby LS, Johnson DS and Baker HW : Adenoid cystic carcinoma of the head and neck. Cancer $29: 1160 \sim 1168$, 1972.

$$
\left(\begin{array}{l}
\text { 原稿受付 : 平成 } 11 \text { 年 } 2 \text { 月 } 9 \text { 日 } \\
\text { 原稿採択 : 平成 } 11 \text { 年 } 4 \text { 月 } 9 \text { 日 } \\
\text { 別刷請求先 : 楠 威志 } \\
\text { 干589-8511 大阪狭山市大野東377-2 } \\
\text { 近畿大学耳鼻咽喉科学教室 }
\end{array}\right.
$$

